\title{
The Suruli shear zone and regional scale folding pattern in Madurai block of Southern Granulite Terrain, south India
}

\author{
V SRINIVASAN ${ }^{1, *}$ and P RAJESHDURAI ${ }^{2}$ \\ ${ }^{1}$ Geological Survey of India, E/5, Arera Colony, Bhopal 462 016, India. \\ ${ }^{2}$ Geological Survey of India, Jawaharlal Nehru Road, Guindy, Chennai 600 032, India. \\ *e-mail: v_srinivasan_geo@rediffmail.com
}

\begin{abstract}
Through the application of remote sensing techniques followed by field checks, the exact extension and nature of Suruli shear zone in Madurai block of southern granulite terrain (SGT) in south India is brought out for the first time in this work. The dominant rock type exposed in this area is charnockite intruded by granites. The Suruli ductile shear zone extends from just west of Kadaiyanallur in the south to Ganguvarpatti in the north over a length of $150 \mathrm{~km}$. Between Kadaiyanallur and Kambam, the shear zone extends roughly in N-S direction. From Kambam, it swerves towards NE and then towards ENE near Ganguvarpatti. The strongly developed transposed foliation and mylonite foliation within the shear zone dip towards east only and so the eastern block (Varushanad hills) is the hanging wall and the western block (Cardamom hills) is the footwall of the shear zone. In the eastern block, three distinct phases of regional scale folding (F1, F2 and F3) are recognized. In complete contrast, the western block recorded only the last phase (F3) regional scale folding. As the more deformed eastern block (older terrain) moved over the relatively less deformed western block (younger terrain) along the Suruli shear zone, it is proposed that this shear zone is a thrust or reverse fault, probably of Proterozoic age. As there are evidences for decreasing displacement from north to south (i.e., from Ganguvarpatti to Kadaiyanallur), the Suruli shear zone could be a rotational thrust or reverse fault with the pivot located close to Kadaiyanallur. As the pivot is located near Achankovil shear zone which trends WNW-ESE (dip towards SSW), the Suruli shear zone could be splaying (branching) out from Achankovil shear zone. In a nutshell, the Suruli shear zone could be a splay, rotational thrust or reverse fault.
\end{abstract}

\section{Introduction}

The Southern Granulite Terrain (SGT), which is the high-grade metamorphic terrain of Tamil Nadu and Kerala in southern India, is traditionally divided into a number of tectonic blocks (figure 1) separated by Proterozoic shear zones (Gopalakrishnan et al 1975; Drury and Holt 1980; Harris and Santosh 1993; Harris et al 1994; Chetty 1996). The present study area covers a part of Madurai block that lies between Palghat-Cauvery shear zone (PCSZ) in the north and Achankovil shear zone (AKSZ) in the south (figure 1).

The dominant rock type exposed in this area is charnockite, associated with khondalite (garnet-biotite-sillimanite gneiss \pm graphite), garnet-cordierite gneiss, migmatitic granite gneiss, garnetiferous quartzo-feldspathic gneiss, calc granulite and quartzite. Thin bands ( 1 to $30 \mathrm{~cm}$ thick) of mafic granulite occur as enclaves in these rock types. Granites and thin veins of pegmatite and quartz intruded these rocks. Remobilised and recrystallised calcite rich veins (crystalline limestone) are aligned mainly along the gneissosity in host charnockite.

Grady (1971) was the first to have pointed out the existence of several deep faults in southern India. The significance of shear zones in the tectonic history of granulite terrain was brought to light by Drury and Holt (1980) and Chetty

Keywords. Suruli shear zone; regional scale folds; Western Ghats Foothill Fault; Madurai block; Southern Granulite Terrain. 


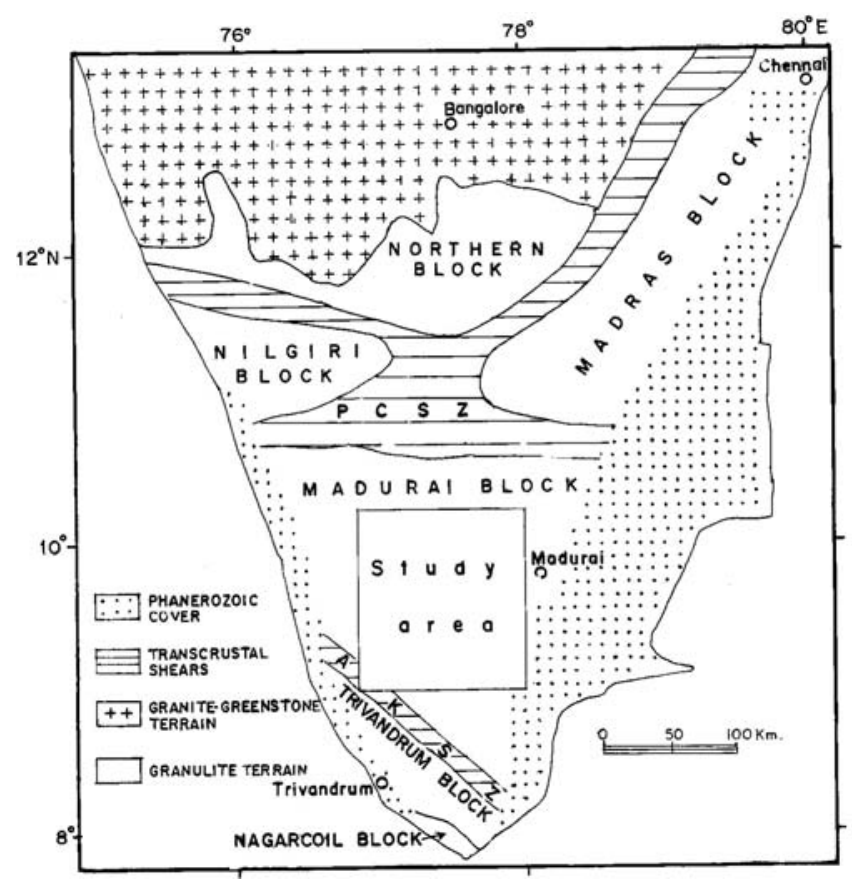

Figure 1. Map showing the different tectonic blocks of SGT (after Santosh 1996) and the study area. PCSZ: PalghatCauvery shear zone; AKSZ: Achankovil shear zone.

(1995) through the study of Landsat TM data. Even though extensive work was done by earlier researchers on many of these shear zones (such as Moyar-Bhavani shear zone, Palghat-Cauvery shear zone, Achankovil shear zone), there are only a few unpublished Geological Survey of India reports on Suruli lineament, also known as Kambam lineament (Balasubramanian and Sundarrajan 1997; Sundaravanan and Mullaivendan 1997; Sundaravanan and Sundarrajan 1999; Sundaravanan 2003). The aim of this work is to map the Suruli lineament and regional scale structures on either side of this lineament through the study of aerial photographs (scale 1:50,000), Digital Image Processing of IRS 1C LISS III satellite digital scenes and extensive field work.

\section{Suruli lineament}

The Suruli lineament aligned along the Suruli river (Kambam valley) extends from Kambam towards NE at least up to Ganguvarpatti (figure 2) and it separates the Varushanad hills in the east from the Cardamom hills in the west. Further NE of Ganguvarpatti (outside the study area), this NE-SW trending Suruli lineament, NW-SE trending Vaigai lineament and N-S trending Vattalakundu-Idayakottai lineament are believed to form a structural conjunction (Balasubramanian and Sundarrajan 1997; Sundaravanan and Mullaivendan 1997; Sundaravanan and Baskaran 1998; Sundaravanan and Sundarrajan 1999).
South of Kambam, the extension of Suruli lineament remained unknown, as the terrain (Western Ghats) is nearly inaccessible. In this work, using remote sensing techniques, the Suruli lineament was traced from Kambam towards south to the east of Periyar Lake and Kakki reservoir up to Kadaiyanallur in the south (figures 2-4). As there are direct field evidences for extensive shearing all along this lineament (i.e., from Kadaiyanallur in the south to Ganguvarpatti in the north), the Suruli lineament is henceforth referred to as 'Suruli shear zone'.

\section{Extension and nature of Suruli shear zone}

The Suruli shear zone divides the terrain into two distinct and contrasting topographic domains. To the east (Varushanad hills), the topography is characterized by ridges and valleys. On the contrary, to the west of the shear zone (Cardamom hills), the topography is massive (figures 3 and 4). The Suruli shear zone delineated in this work extends almost along the contact of 'zones of predominantly Archaean supracrustals' in the east and 'zones of predominantly granulite orthogneiss' in the west (Drury et al 1984).

\subsection{Extension of Suruli shear zone}

Strongly developed foliation all along this shear zone is very characteristic and the attitude of this transposed planar fabric gives the overall attitude of the Suruli shear zone (figure 5). Along the transposed foliation plane, there are few evidences for stretching lineations that plunge at high angle (70 to $80^{\circ}$ towards ENE), which may be parallel to the shear direction. Attitude measurements of the foliation from Kambam to Ganguvarpatti reveal that the shear zone swerves gradually from NE-SW (near Kambam in the south) to ENEWSW (east of Vaigai reservoir and Ganguvarpatti in the north), but the dip direction is always towards east. For example, the mylonite foliation at $2 \mathrm{~km} \mathrm{SE}$ of Kombi (figure 2), strikes between $\mathrm{N} 50^{\circ} \mathrm{E}$ and $\mathrm{N} 60^{\circ} \mathrm{E}$ with a low dip of $30^{\circ}$ due SE. But in the north at $3 \mathrm{~km} \mathrm{NE}$ of Vaigai reservoir (figure 2), the mylonite foliation (figure 6) strikes between $\mathrm{N} 65^{\circ} \mathrm{E}$ and $\mathrm{N} 75^{\circ} \mathrm{E}$ with a low dip of around $30^{\circ}$ due south. Very close to the margin of the shear zone there are evidences for ductile polyphase folding deformation (figure 7) and the transposed foliation within the shear zone is parallel to the axial plane of these isoclinal as well as reclined folds. The shear zone is ductile in nature as the deformation state varies continuously from wall to wall across the shear zone. Just west of 


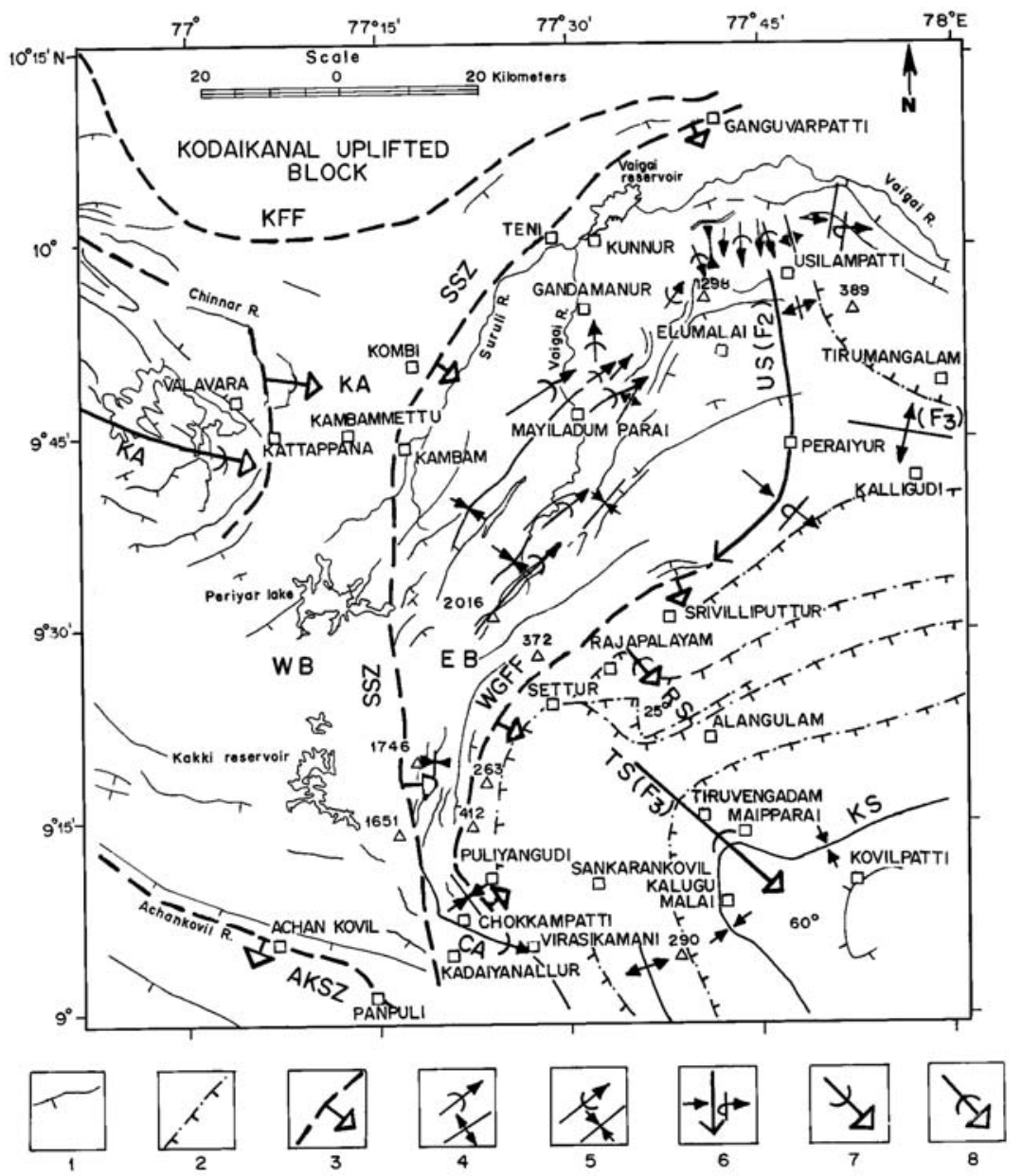

Figure 2. Regional structural map of part of Madurai block of SGT prepared through remote sensing study and field checks. (1) Crest line of strike ridge, the short line shows the dip slope, (2) the dominant gneissic trend, the short line shows the dip direction of gneissosity, (3) major fault/shear zone, the arrow shows the dip direction of the weaker zone, (4) F1 regional scale antiform (plunging/nonplunging), (5) F1 regional scale synform (plunging/nonplunging), (6) F2 regional scale synform, (7) F3 regional scale plunging antiform, (8) F3 regional scale plunging synform.SSZ: Suruli shear zone, EB: eastern block (hanging wall) of Suruli shear zone, WB: western block (footwall) of Suruli shear zone, WGFF: Western Ghats Foothill Fault, AKSZ: Achankovil shear zone, KFF: Kodaikanal Foothill Fault. CA: Chokkampatti antiform (F1), US: Usilampatti synform (F2), KS: Kallugumalai synform (F2?), TS: Tiruvengadam synform (F3), RS: Rajapalayam synform (F3), KA: Kattappana antiform (F3).

Kambam, the carbonatite intrusive in this shear zone (Balakrishnan et al 1985; Sundaravanan 2003) seems to indicate that it could be a deep fault as Grady (1971) suggested that carbonatites occur along deep faults. In Kambam valley (Suruli River) Francis Anto et al (1997) reported close spatial and temporal association of sapphirine bearing assemblages $\left(T=850^{\circ} \mathrm{C}\right)$ with the deep seated Kambam fault (i.e., Suruli shear zone in this work) and proposed that this intracratonic lineament belongs to Pan-African age (800-670 Ma).

As mentioned earlier, the extension of Suruli shear zone to the south of Kambam remained unknown, as the terrain (Western Ghats) is nearly inaccessible. Using remote sensing techniques, this shear zone could be traced from Kambam towards south up to Kadaiyanallur (figures 2-4). About
$10 \mathrm{~km} \mathrm{NW}$ of Kadaiyanallur, the shear zone is exposed and the transposed foliation along this shear zone strikes $\mathrm{N} 5^{\circ} \mathrm{W}$ with a steep dip of $\sim 60^{\circ}$ due east. Here the shear zone flanks the western limb of Chokkampatti antiform (CA in figure 4, discussed later). West of the shear zone $(5 \mathrm{~km}$ north of Panpuli), the lithological contact and co-planar gneissosity in charnockite strike $\mathrm{N} 55^{\circ} \mathrm{W}$ to $\mathrm{N} 75^{\circ} \mathrm{W}$ with steep dip of 50 to $70^{\circ}$ due south.

The Suruli shear zone separates two distinct topographic as well as structural domains. The eastern block of this shear zone (EB in figure 2) is characterized by N-S to NE-SW trending regional scale fold belt (figures 3 and 4 ), which is typically absent in the western block (WB in figure 2). The width of the shear zone increases from south to north (i.e., from Kadaiyanallur towards 


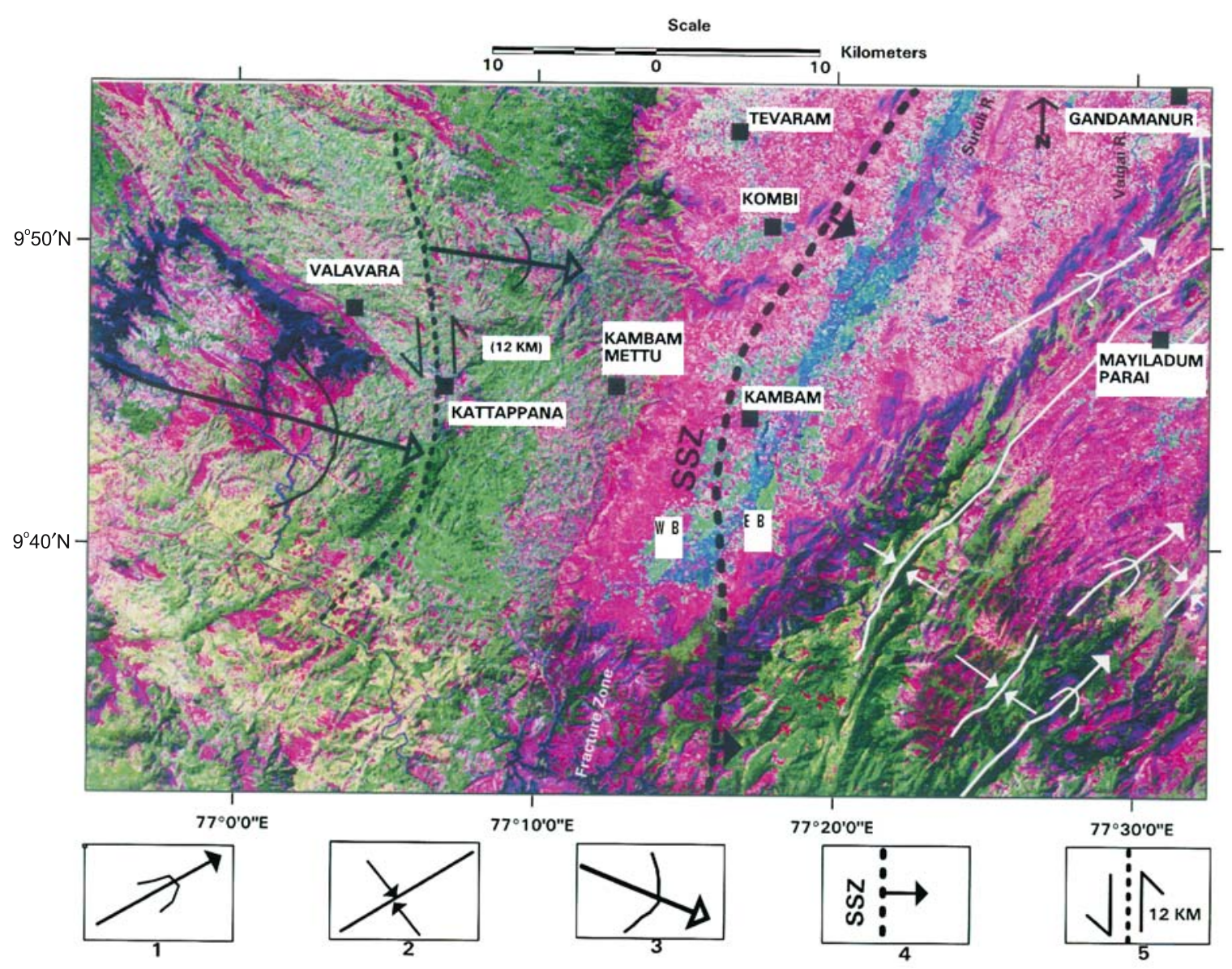

Figure 3. The satellite imagery depicting the contrasting folding pattern in the east and in the west of Suruli shear zone (SSZ). East of SSZ: (1) plunging antiform of F1 fold belt, (2) synform of F1 fold belt. West of SSZ: (3) F3 plunging antiform (Kattappana antiform). (4) Suruli shear zone (SSZ) dipping towards east, (5) strike slip fault (sinistral) that dissected the nose part of Kattappana antiform and displaced it over a distance of $12 \mathrm{~km}$.

Ganguvarpatti). In the south, the width of the shear zone is about $200 \mathrm{~m}$, which increases to $10 \mathrm{~km}$ in the north. Even the intensity of deformation increases from south to north along this shear zone. In the northern end, between Vaigai River and Ganguvarpatti, there are many exposures of mylonite that were not observed in the southern end (i.e., near Kadaiyanallur). It is suggested that the Suruli shear zone dies out towards south (Kadaiyanallur side) and merges with the WNWESE trending Achankovil shear zone. The map pattern (figure 2) gives the impression that the Suruli shear zone (SSZ) splays out from Achankovil shear zone (AKSZ), extends towards north and then towards NE. Invariably the dip direction of Suruli shear zone is towards east only and so the eastern block (EB in figure 2) is the hanging wall and the western block (WB in figure 2) is the footwall.

\subsection{Nature of Suruli shear zone}

To know whether the eastern block (hanging wall) is up thrown or down thrown with respect to the western block (footwall), the regional scale structures in both the blocks were studied using remote sensing techniques followed by extensive field checks. As the eastern block has complex regional scale folding pattern as compared to the western block, it is suggested that the more deformed eastern block (equivalent to 'zones of predominantly Archaean supracrustals' of Drury et al 1984 ) is older than the western block (equivalent to 'zones of predominantly granulite orthogneiss' of Drury et al 1984).

\subsubsection{Regional scale folding pattern in eastern block (hanging wall) of Suruli shear zone}

At many places it is observed that the gneissosity (i.e., differentiated layering) in charnockite which is the dominant rock type is parallel to the gneissosity of the associated quartzo-feldspathic gneiss, granite gneiss and khondalite and this pervasive and penetrative gneissosity is also parallel to the lithological contacts. Everywhere as this gneissosity is 


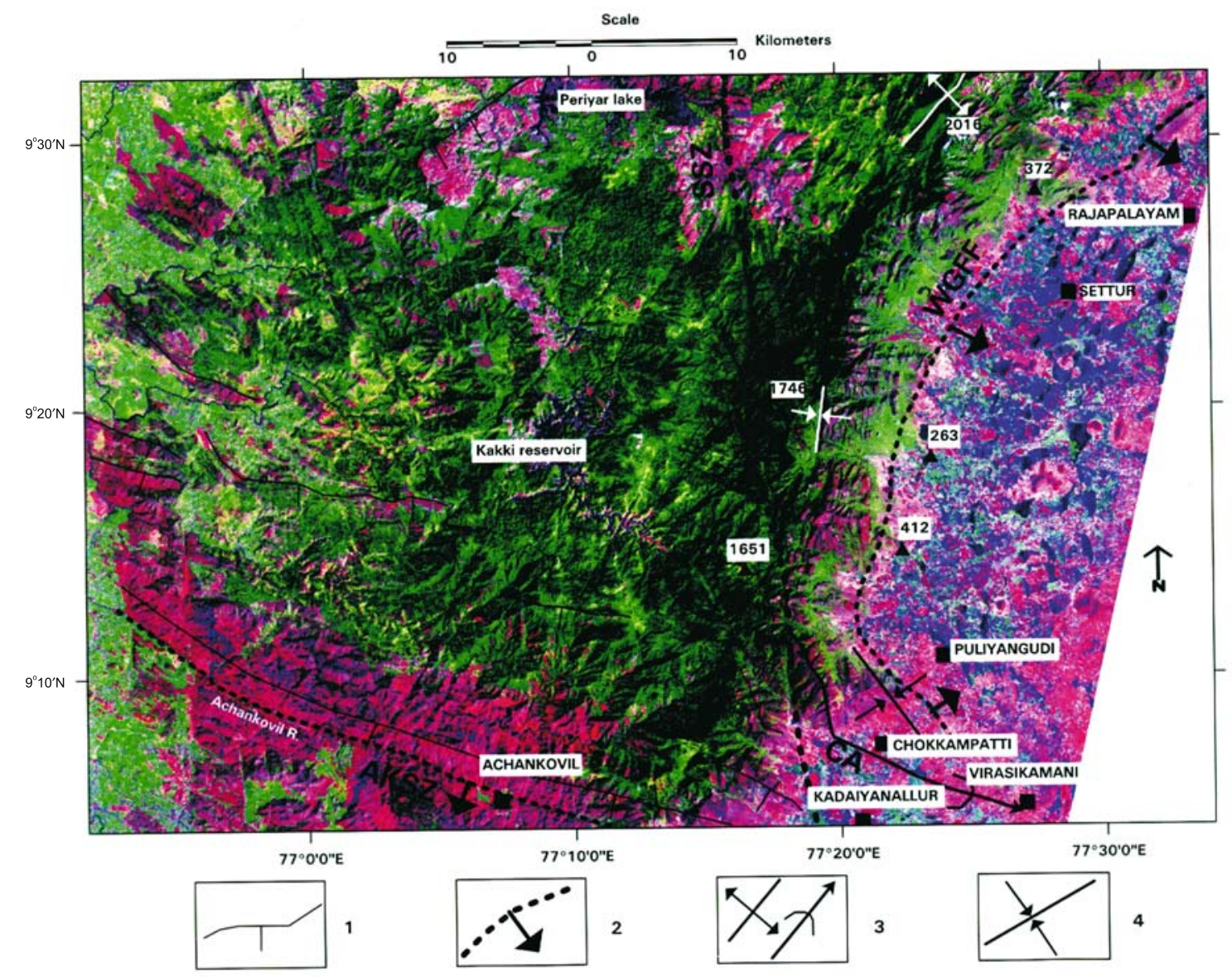

Figure 4. The satellite imagery showing the southern extension of Suruli shear zone (SSZ). To the east of SSZ, the curvilinear shape of F1 fold belt and Western Ghats Foothill Fault (WGFF) with the concavity facing SE is evident. To the west of SSZ, the southern limb of Kattappana antiform (F3), the closure of which is shown in figure 3, extends up to Achankovil shear zone (AKSZ) in the south. (1) Crest line of strike ridge, the short line shows the dip slope, (2) Major fault/shear zone, the arrow shows the dip direction of the weaker zone. East of SSZ: (3) F1 regional scale antiform, (4) F1 regional scale synform. CA: Chokkampatti antiform in the southern end of F1 folds belt plunges towards SSE and then ESE.

parallel to the axial plane of mesoscopic isoclinal folds (figure 8), it is believed that the gneissosity (differentiated layering) could have formed during the initial compressive stage, probably in deep-seated, ductile, high-grade metamorphic environment (Rajeshdurai et al 2008). After the development of pervasive gneissosity, there are three distinct phases of regional scale folding (F1, F2 and F3) in the eastern block and these regional scale folds control the topography.

The fold belt of Western Ghats lying immediately to the east of Suruli shear zone belongs to the first phase of regional scale folding (F1) and this fold belt is typically absent to the west of shear zone. The fold belt is curvilinear with the concavity facing SE. As will be demonstrated subsequently, this curvilinear shape is due to the superposition of a later regional scale folding (F3) on this F1 fold belt. In the southern end of F1 fold belt, the Chokkampatti antiform (CA in figures 2, 4, 9A) was studied in the field. Based on measurements made in the eastern limb, western limb and closure part of this fold, it is found that this antiform plunges $\sim 30^{\circ}$ due $\mathrm{S} 20^{\circ} \mathrm{E}$. As mentioned earlier, the southern end of Suruli shear zone flanks the western limb of this antiform. Further down the plunge direction (i.e., towards SSE), the hinge of this antiform swerves from NNWSSE to WNW-ESE up to Virasikamani. So in the southern end of this F1 fold belt, the folds swerve from NNW-SSE to WNW-ESE in the plunging direction (SSE to ESE). Contrastingly, the folds in the northern part of F1 fold belt trend NE-SW with the dominant plunge direction towards NE (figures 2 and 3 ). The road connecting Elumalai and Mayiladumparai (figures 2 and 10) transects this fold belt (figures 9B, C) and here for one such fold the plunge was measured to be around $20^{\circ}$ towards NE.

In figure 10, it is evident that the NE-SW trending F1 fold belt (Varushanad hill range) in the west swerves towards east and then towards SE 


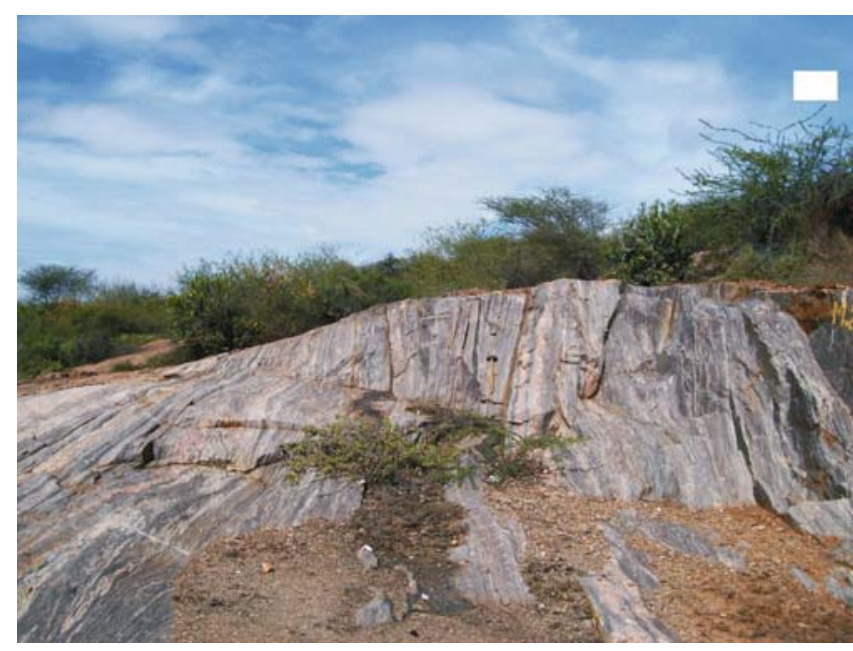

Figure 5. The strongly developed transposed foliation all along the extension of Suruli shear zone is very characteristic. Here (near Teni) the foliation strikes around $\mathrm{N} 50^{\circ} \mathrm{E}$ with steep dip of 70 to $80^{\circ}$ due SE (i.e., towards left side of photo). Garnet, cordierite profusely developed and sapphirine is also reported along this zone. The younger granites (like pink granite) intruded along the foliation planes in this zone are also sheared with the development of co-planar foliation planes in them.

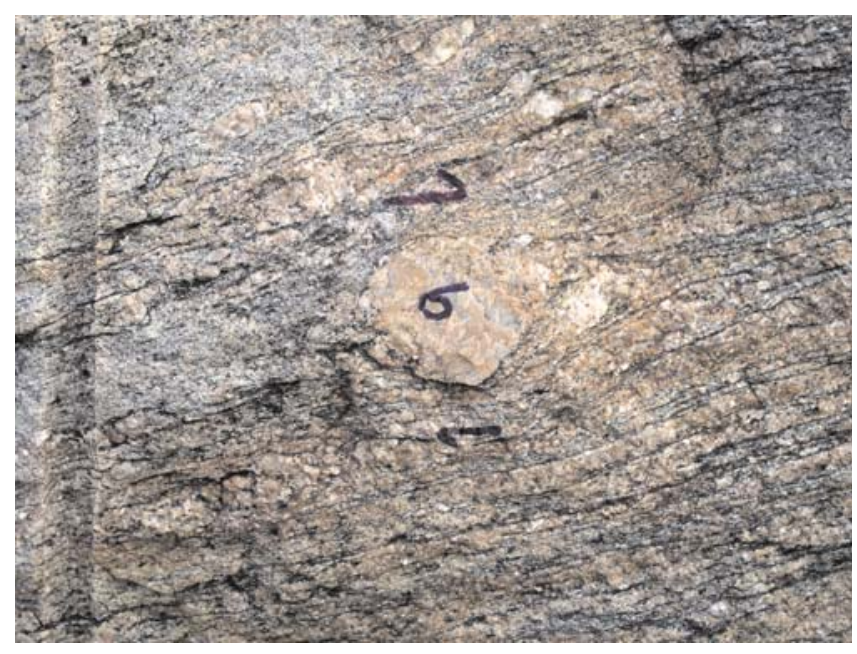

Figure 6. Mylonite along Suruli shear zone. Near Vaigai reservoir, the foliation in the mylonite outcrop strikes $\mathrm{N} 75^{\circ} \mathrm{E}$ with a shallow of $30^{\circ}$ towards south. Hair-thin pseudo tachylite layers aligned roughly along mylonite foliation plane can also be seen.

around Usilampatti with the limbs of $\mathrm{F} 1$ folds tightly oppressed. The area around Usilampatti falls on the closure part of this F2 regional scale fold, which is named as Usilampatti synform (US in figures 2 and 10). In the broad closure zone of about $15 \mathrm{~km}$ wide (between A and B in figure 10), there are many folds (MW type) that trend NNWSSE and plunge towards SSE (see, Sanjeevi and Bhaskar 2008 for Digital Elevation Model (DEM) of this area). In the western limb of this F2 Usilampatti synform (foothill of Varushanad hill range,

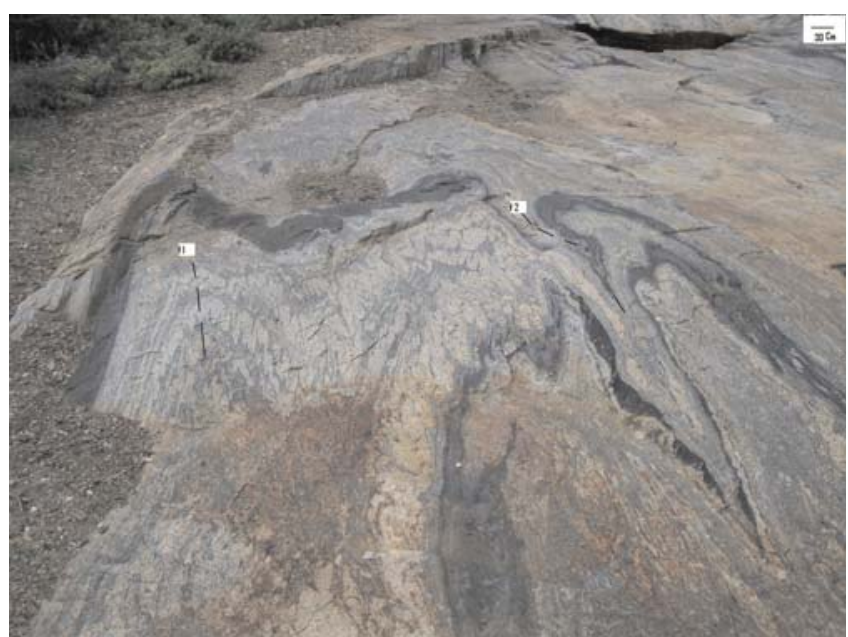

Figure 7. In the margin of the Suruli shear zone, there is evidence for poly phase folding deformation and the axial planes of these folds are parallel to the strongly developed transposed foliation within the adjoining shear zone. Here (near Teni) the actual shear zone (shown in figure 5) is located west of these folds (i.e., right side of this photo) and the axial planes of these mesoscopic folds $\left(f_{1}\right.$ and $\left.f_{2}\right)$ are nearly parallel to the foliation planes within the shear zone. There is an increase in intensity of deformation from the margin (wall) part of the shear zone into the shear zone and it is pertinent to note that the wall or margin part of this shear zone is not at all sharp and distinct.

SW of Elumalai in figure 10), the charnockitequartzite sequence strike $\mathrm{N} 20^{\circ} \mathrm{E}$ to $\mathrm{N} 30^{\circ} \mathrm{E}$ with a steep dip of 75 to $80^{\circ}$ due east. Here even the pervasive gneissosity strikes $\mathrm{N} 25^{\circ} \mathrm{E}$ to $\mathrm{N} 30^{\circ} \mathrm{E}$ with a steep dip of $70^{\circ}$ due east. About $5 \mathrm{~km}$ south of Usilampatti (figure 10), from west to east, the lithological contact and pervasive gneissosity swerve from $\mathrm{N} 65^{\circ} \mathrm{E}$ (dip 40 to $50^{\circ}$ towards $\mathrm{SE}$ ) to $\mathrm{S} 50^{\circ} \mathrm{E}$ (dip 65 to $75^{\circ}$ towards SW) and then to $\mathrm{S} 20^{\circ} \mathrm{E}$ (dip 65 to $85^{\circ}$ towards west). The Usilampatti-Peraiyur road is aligned along the hinge zone of this SSE plunging Usilampatti synform (figure 10). In the eastern limb, only close to the hinge zone the dip direction is towards west (inward dip direction). But further east of the hinge zone, the eastern limb dips towards east and is separated from the hinge zone by a highly deformed horizon. This structural setup is clearly exposed NE of Srivilliputur, just before reaching Krishnankovil (discussed later). So the western limb and the hinge zone of Usilampatti synform constitute one block, while the eastern limb is separated from this block by a major fault. Here it is suggested that this easterly dipping eastern limb of Usilampatti synform could be overturned. All along the hinge zone (Usilampatti-Peraiyur road), the fracture cleavage of Usilampatti synform (parallel to the axial surface) is well developed and this cleavage zone along the hinge is in orthogonal relationship with the bedding contacts and co-planar 


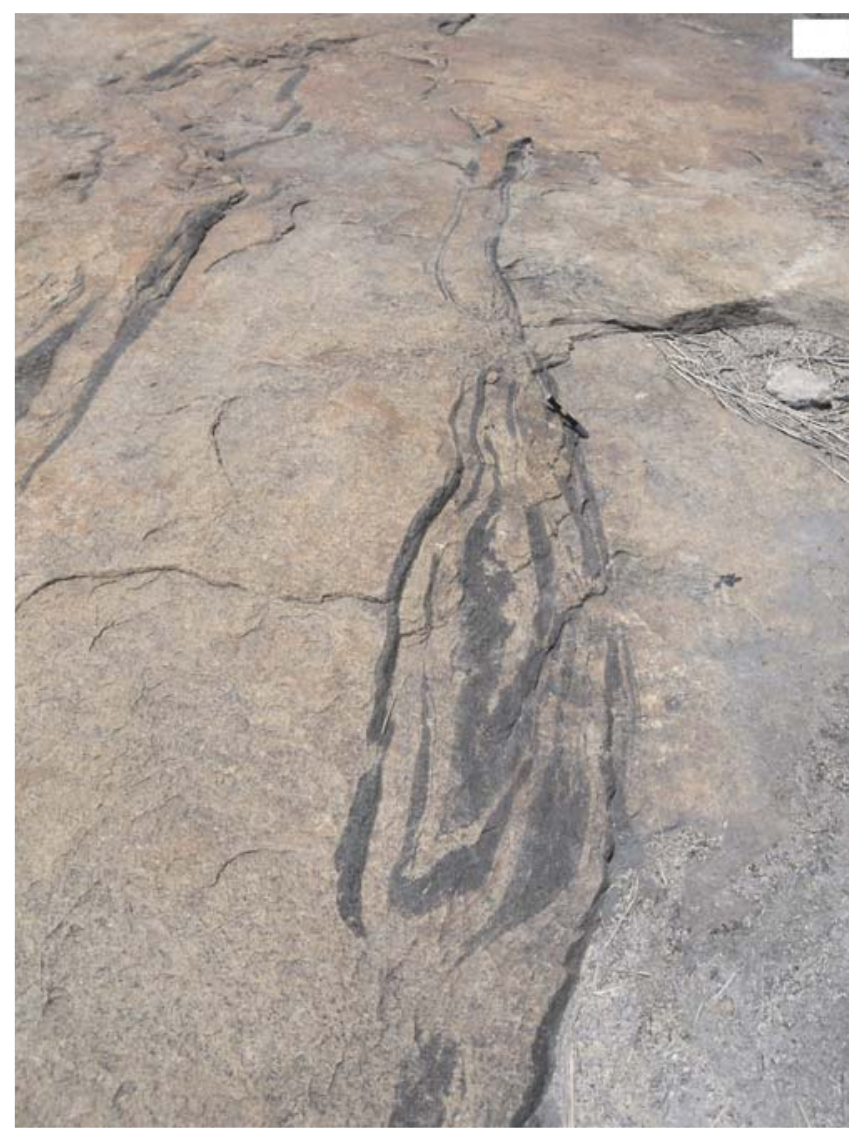

Figure 8. The gneissosity (differentiated layering) in charnockite is parallel to the axial plane of mesoscopic folds in charnockite, supporting the view that the layering developed during this initial folding deformation, most probably in deep-seated ductile environment. These folds as revealed by basic bands in charnockite are mostly isoclinal as well as reclined. In this outcrop (Loc: $7.5 \mathrm{~km} \mathrm{NE}$ of Tiruvengadam) the axial plane of this isoclinal, reclined fold and the gneissosity in the host charnockite strike $\mathrm{N} 55^{\circ} \mathrm{E}$ and dip $45^{\circ}$ due SE (i.e., towards top side of photo).

pervasive gneissosity in the charnockite and the associated granite gneiss (figure 11). At Peraiyur in the hinge zone, while the bedding contacts strike E-W (dip due south), the axial plane parallel cleavage zone strikes NNW-SSE with a very steep dip due west. We propose that the hinge zone of Usilampatti synform extends from Andipatti hills (MW folds in the closure, north of Usilampatti) towards SSE up to Peraiyur (figure 10) and the plunge direction is towards SSE. Further south of Peraiyur, the hinge zone of Usilampatti synform bends towards SW, with the plunge direction towards SW. Here in the eastern limb, the quartzites strike $\mathrm{N} 20^{\circ} \mathrm{E}$ to $\mathrm{N} 25^{\circ} \mathrm{E}$ with a steep dip of 70 to $75^{\circ}$ towards east. About $8 \mathrm{~km} \mathrm{NE}$ of Srivilliputur (figure 2), close to Krishnankovil, the chute like SW plunging hinge of this synform is well exposed. From west to east, the bedding contacts of charnockite (with enclaves of pyroxene granulite), quartzo-feldspathic gneiss, granite gneiss and
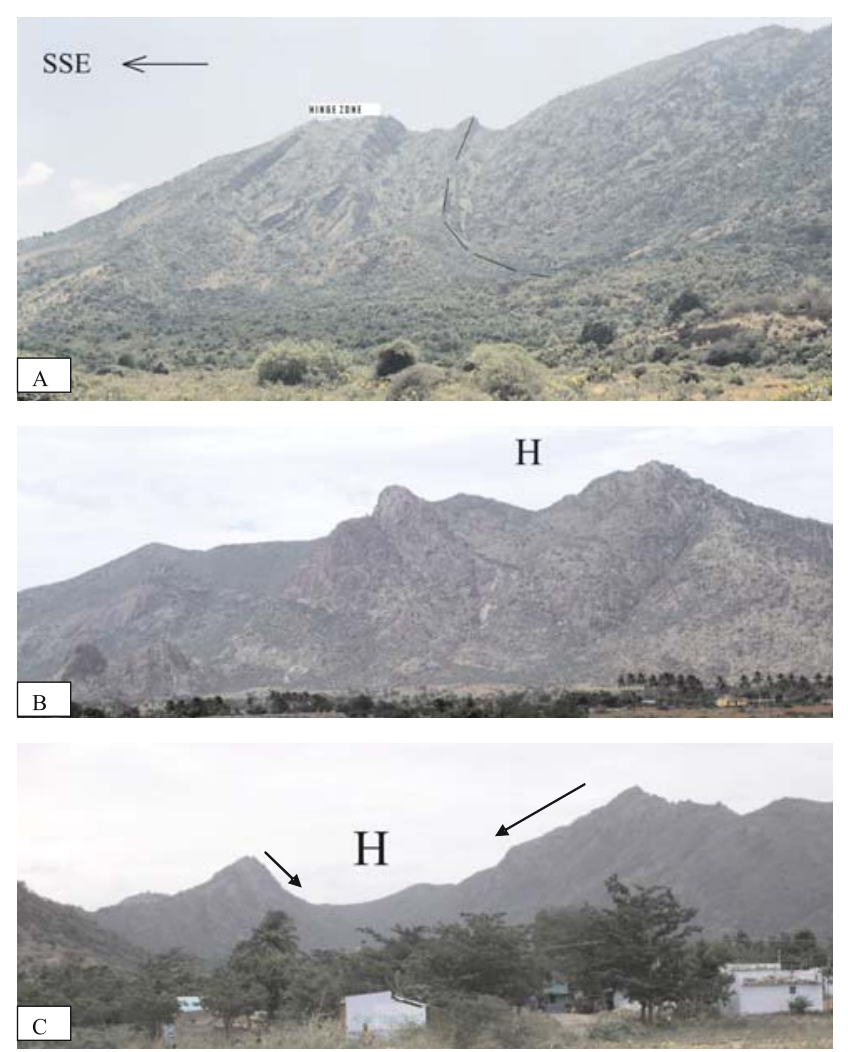

Figure 9. F1 mega folds. (A) Chokkampatti antiform in the southern end of F1 fold belt. The eastern limb and hinge zone of Chokkampatti antiform is visible in this photo. This fold is plunging about $30^{\circ}$ towards $\mathrm{S} 20^{\circ} \mathrm{E}$ (i.e., towards left side of photo). Further down the plunge direction, the hinge zone of this fold swerves from SSE towards ESE as seen just west of Virasikamani. (B) While the folds in the southern extension of F1 fold belt plunge towards SSE and then towards ESE, the folds in the northern extension of F1 fold belt trend NE-SW and plunge mainly in $\mathrm{NE}$ direction and this can be clearly seen in aerial photos. Loc: $10 \mathrm{~km}$ east of Gandamanur. The gneissic charnockite and garnet-cordierite gneiss are folded into an open synform. H-Hinge zone. (C) Loc: Mayiladumparai. The gneissic charnockite, quartzite, granite gneiss and garnet-cordierite gneiss are folded into an open synform and based on measurements made in the hinge zone $(\mathrm{H})$ in the field it is found that this fold is plunging around $20^{\circ}$ towards NE.

the co-planar pervasive gneissosity swerve from $\mathrm{N} 45^{\circ} \mathrm{E}$ (dip $70^{\circ}$ due SE) to $\mathrm{N} 85^{\circ} \mathrm{E}$ (dip $40^{\circ}$ due $\mathrm{S}$ ) to $\mathrm{S} 50^{\circ} \mathrm{E}$ (dip $40^{\circ}$ due $\mathrm{SW}$ ) to $\mathrm{S} 10^{\circ} \mathrm{E}\left(\operatorname{dip} 32^{\circ}\right.$ due $\mathrm{W}$ ) and finally to $\mathrm{S} 30^{\circ} \mathrm{W}$ (dip $55^{\circ}$ due $\mathrm{W}$ ). Just east of this SW plunging chute like closure, a $50 \mathrm{~m}$ wide zone trending $\mathrm{N} 65^{\circ} \mathrm{E}$ to $\mathrm{N} 70^{\circ} \mathrm{E}$ with highly contorted gneissosity and extensive development of garnet porphyroblasts is exposed. This zone could be a ductile shear zone and it separates the closure (hinge zone) of Usilampatti synform from the eastern limb, where the bedding contacts of charnockite and granite gneiss with pervasive gneissosity strike around $\mathrm{N} 50^{\circ} \mathrm{E}$ with a steep dip of about $75^{\circ}$ due SE. The closure (hinge) part of Usilampatti synform is very wide in the north (i.e., 


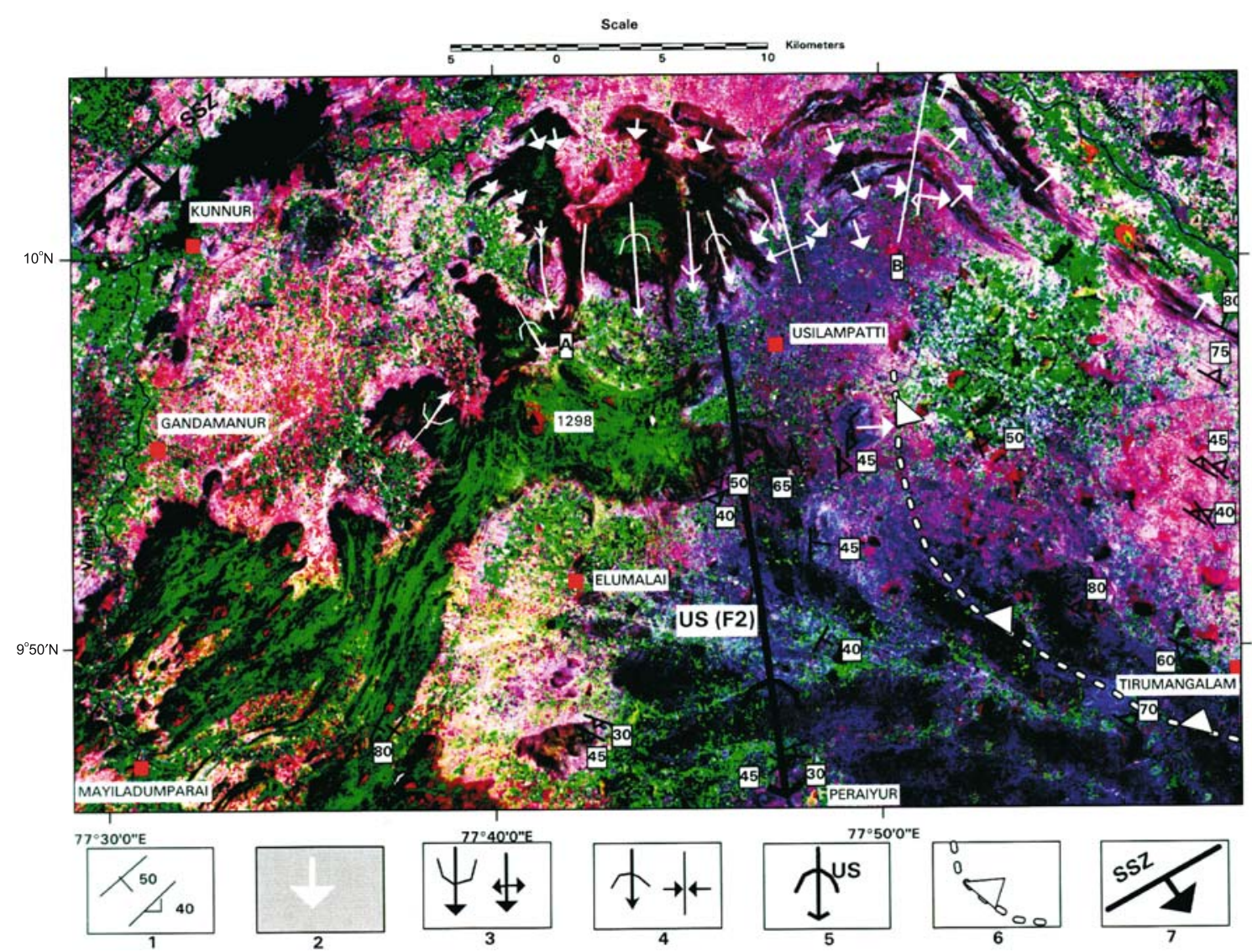

Figure 10. The satellite imagery showing the SSE plunging Usilampatti synform (US), which belongs to F2 phase regional scale folding. The MW folds in its closure (between 'A' and 'B') trend NNW-SSE and plunge towards SSE as in the case of Usilampatti synform. In the western limb of US, the folds of F1 fold belt trend NE-SW and plunge mainly towards NE (see figure 3) and the fold belt swerves towards east and then towards SE with the limbs of F1 folds becoming tightly oppressed. Post tectonic granite intrusion (hill 1298) and massive, non-gneissic charnockite intrusion (just east of Kunnur) are structurally controlled. (1) Bedding attitude and gneissic attitude measured in the field, (2) dip slope direction of strike ridge. North of Usilampatti, in the closure of US, the dip slope direction of strike ridges is towards south, whereas in the $\mathrm{NE}$ and east of Usilampatti, in the eastern limb of US, the dip slope direction is towards NE as the strike ridges here trend NW-SE. The eastern limb of US could be overturned. (3) Antiforms of MW type in the closure of US (between 'A' and 'B'), trend NNW-SSE and plunge towards SSE, (4) Synforms of MW type in the closure of US, trend NNW-SSE and plunge towards SSE, (5) Usilampatti synform (US) plunging towards SSE, (6) The regional gneissic attitude (triangle showing the dip direction of gneissosity) in the eastern limb of US, (7) Suruli shear zone (SSZ, in the NW corner) dipping towards SE.

about $15 \mathrm{~km}$ wide, between $\mathrm{A}$ and $\mathrm{B}$ in figure 10). But in the south $(8 \mathrm{~km} \mathrm{NE}$ of Srivilliputur), the width of the closure is around 2 to $3 \mathrm{~km}$. Further down the plunge direction (i.e., towards SW), this synform is not exposed due to soil cover. Instead, along the same trend of the hinge zone of Usilampatti synform, a major fault (Western Ghats Foothill Fault) extends along the foothill of Western Ghats up to Puliyangudi in the south (figures 2 and 4) and the trace of this fault is also curvilinear (concavity facing SE) as in the case of the F1 fold belt that forms the western block of this fault.

The Western Ghats Foothill Fault (WGFF) separates the Western Ghats (F1 fold belt) from the plain area in the east. Evidence for extensive shearing was observed in the field all along this fault (figure 12). West of Rajapalayam, the foliation developed due to shearing along this fault strikes $\mathrm{N} 65^{\circ} \mathrm{E}$ to $\mathrm{N} 70^{\circ} \mathrm{E}$ with a steep dip of 60 to $65^{\circ}$ towards east. Even the quartz reefs intruded along this fault dip steeply due east. Further south, near 412 triangulation point (figure 4), the trend of this fault is around $\mathrm{N} 5^{\circ} \mathrm{W}$ with a steep dip of $70^{\circ}$ towards east. Just west of Puliyangudi, in the southern end of this fault, its attitude is $\mathrm{N} 15^{\circ} \mathrm{W}$ with a steep dip of around $80^{\circ}$ towards east. The dip direction of this fault is towards east only and the eastern block, low-lying area with few denudational hills, could be down thrown with respect to the western block (i.e., Western Ghats area) and so the Western Ghats Foothill Fault is a normal fault. There are field evidences for reactivation of this fault; especially after the intrusion of quartz reef along this fault (figure 13) and 


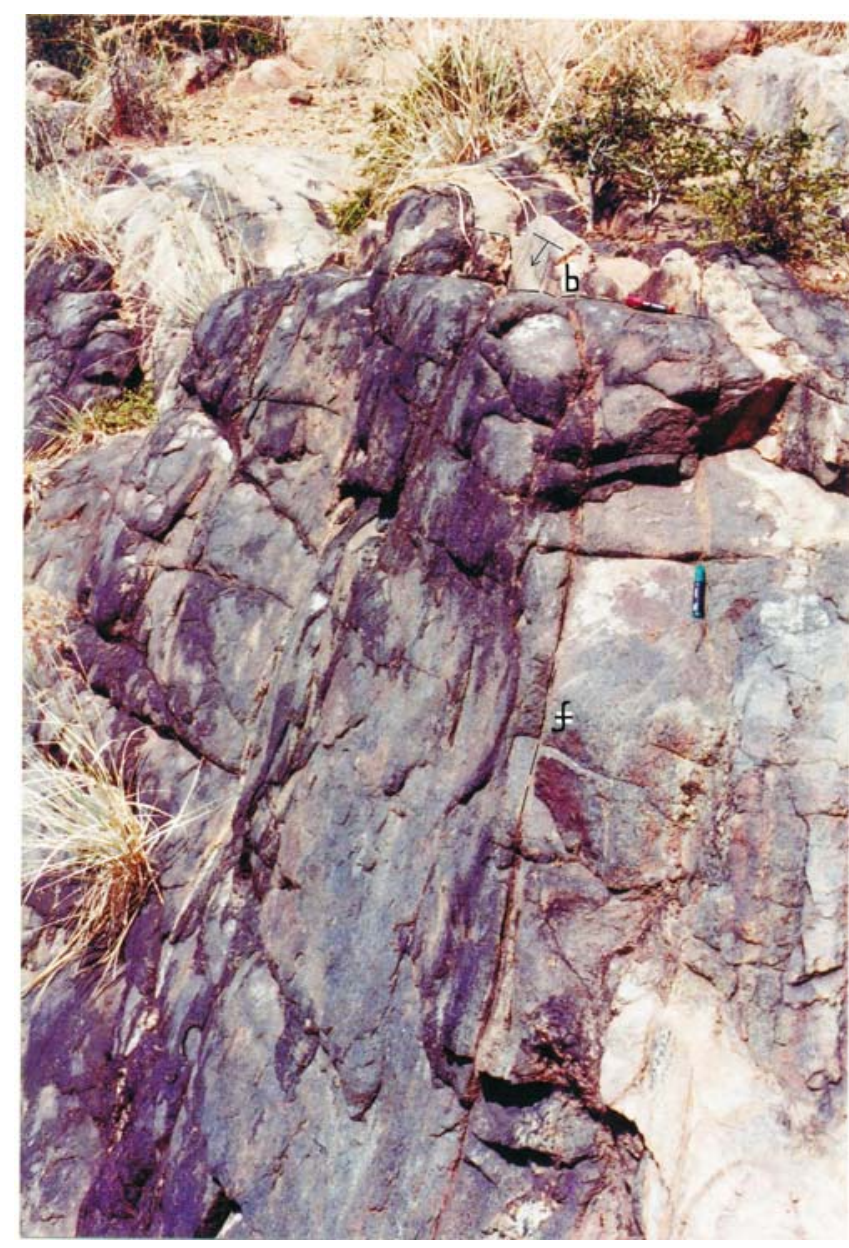

Figure 11. Axial zone of Usilampatti synform (F2 regional scale folding). The orthogonal relationship in the core zone can be seen at the outcrop level. Loc: Peraiyur. Here in leucocratic granite, the fracture cleavage (f) that is parallel to axial surface of Usilampatti synform, strikes $\mathrm{N} 25^{\circ} \mathrm{W}$ (dip 70 to $74^{\circ}$ due west) and the bedding contact (b) shown by basic granulite band strikes $\mathrm{N} 65^{\circ} \mathrm{W}$ (dip $63^{\circ}$ due south). In this photo, the camera is facing north.

even during reactivation, the sense of movement remained same (i.e., the western block is up thrown relative to the eastern block). The curvilinear pattern of this fault (similar to F1 fold belt) is again due to the interference effect of last phase regional scale folding (F3).

The area lying to the east of Western Ghats Foothill Fault is a low-lying area with extensive soil cover (figure 4) and in this area the pervasive gneissosity was measured in the field at a number of places by Srinivasan and Rajeshdurai (2009) and the poles of this planar element were plotted on the Equal-area (Schmidt) net to find the attitude of the last phase (F3) regional scale folding. In the SE part of figure 2, the dominant gneissic trend as measured in the field is shown. Tiruvengadam synform (TS in figure 2) is an open synformal warp and based on lower hemisphere equal area projection of the poles of pervasive gneissosity,

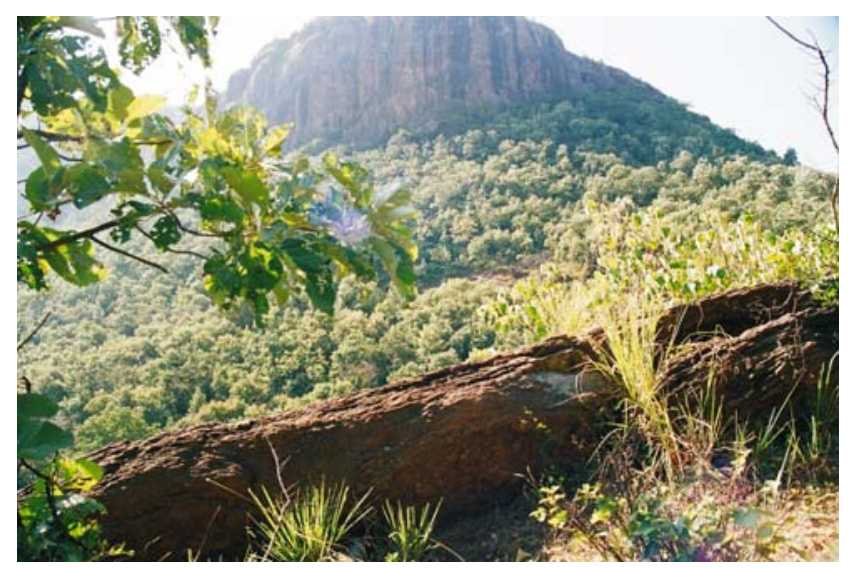

Figure 12. Western Ghats Foothill Fault. Shearing along the Western Ghats Foothill Fault produced pronounced foliation. In this outcrop (west of Rajapalayam, close to 372 triangulation point), the foliation planes strike $\mathrm{N} 65^{\circ} \mathrm{E}$ with steep dip of $60^{\circ}$ towards SE. This fault zone separates the Western Ghats (F1 fold belt) in the west from the plain with few denudational hills in the east. Within the highly sheared foliation zone along the fault (bottom of the photo, extending from left to right) even proto-mylonite are exposed. The charnockite hill is in the eastern downthrown block of this fault.

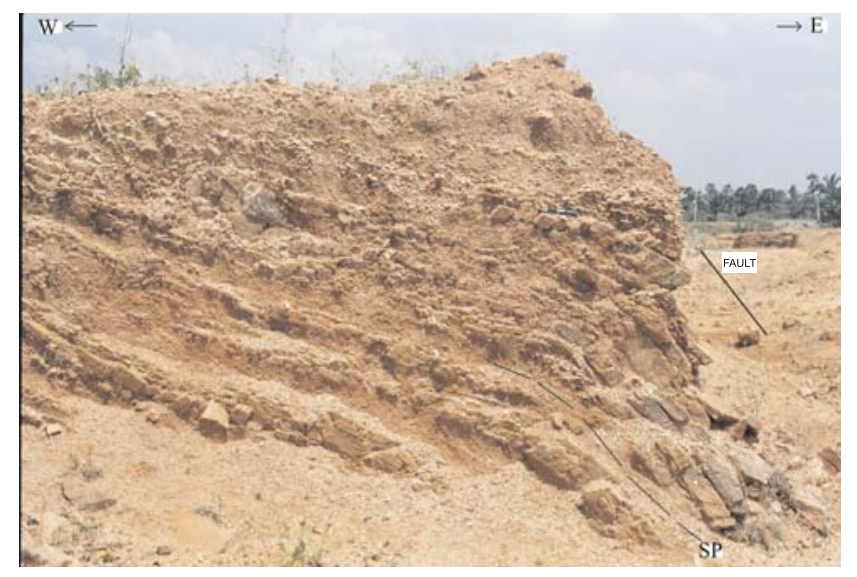

Figure 13. Along the Western Ghats Foothill Fault, the quartz reef that was intruded was sheared and faulted due to repeated reactivation of this fault. The quartz in quartz reef is pulverized along the shear plane (SP) and this shear plane is again faulted, as it is evident by the drag effect in this photo. Interestingly even in the case of later reactivation (FAULT), the sense of movement remained same (i.e., the western block is up thrown with respect to the eastern block). In this location (north of 412 triangulation point), the Western Ghats Foothill Fault extends roughly in N-S direction and dips steeply towards east.

it is found that this warp is plunging $60^{\circ}$ towards $\mathrm{S} 44^{\circ} \mathrm{E}$ (figure 14). Within Tiruvengadam synform, the hinge of earlier (F2?) mega fold (Kallugumalai synform (KS) in figure 2) is also warped. The curvilinear pattern of F1 fold belt (Western Ghats) and Western Ghats Foothill Fault is due to the interference effect of this last phase (F3) regional scale warping (i.e., Tiruvengadam synform). 
Based on the reversal in dip direction of pervasive gneissosity, an open antiformal warp, which is complimentary to Tiruvengadam synform, is proposed between Kalligudi and Tirumangalam (eastern margin of figure 2) and this F3 regional scale antiformal warping could have caused the bending in the hinge zone of Usilampatti synform (F2).

Within Tiruvengadam synform, towards Western Ghats Foothill Fault, few 'Z' shaped regional scale flexures exist and one such fold at Rajapalayam is named as 'Rajapalayam synform' (RS in figure 2) and it can be seen in aerial photos and satellite imagery. It is an asymmetrical synform with the western long limb dipping gently $\left(\sim 30^{\circ}\right)$ towards SE and the eastern short limb dipping steeply $\left(\sim 80^{\circ}\right)$ towards west. Lower hemisphere equal area projection of poles of pervasive gneissosity and lithological contacts reveal that the Rajapalayam synform is plunging $25^{\circ}$ towards $\mathrm{S} 40^{\circ} \mathrm{E}$ (figure 15 ). This ' $\mathrm{Z}$ ' shaped regional flexure dies out in the plunge direction (figure 2).

F3 warps (Tiruvengadam synform and the complimentary antiform between Kalligudi and Tirumangalam in figure 2) could have formed due to the on play of compressive force in NNESSW to NE-SW direction. The ' $Z$ ' shaped flexures close to Western Ghats Foothill Fault could be due to the strike slip movement (dextral) along this fault during F3 phase. It is suggested that along the Western Ghats Foothill Fault, which is a normal fault, there could be later strike slip movement (dextral) and this strike slip movement could have developed ' $Z$ ' shaped flexures (like Rajapalayam synform) in the eastern down thrown block during F3 folding phase. In fact this F3 warping (on-play of NNE-SSW to NE-SW compressive forces) affected the whole terrain including the western block (footwall) of Suruli shear zone.

\subsubsection{Regional scale folding pattern in western block (footwall) of Suruli shear zone}

There are only two regional scale structures in the western block: Kattappana antiform (KA in figure 2) and Kodaikanal uplifted block bounded by Kodaikanal Foothill Fault (KFF in figure 2). Kattappana antiform is an open antiform plunging towards ESE (figure 3). The southern limb of this antiform extends up to Achankovil shear zone in the south and the northern limb extends up to Kodaikanal Foothill Fault in the north (figure 2). The closure (nose) of this fold is truncated by $\mathrm{N}-\mathrm{S}$ trending strike slip fault that extends through Kattappana along Chinnar River. Along this fault, the truncated and displaced nose part of this fold shows an offset of $12 \mathrm{~km}$ in counter clockwise direction (i.e., sinistral movement) and it can be seen

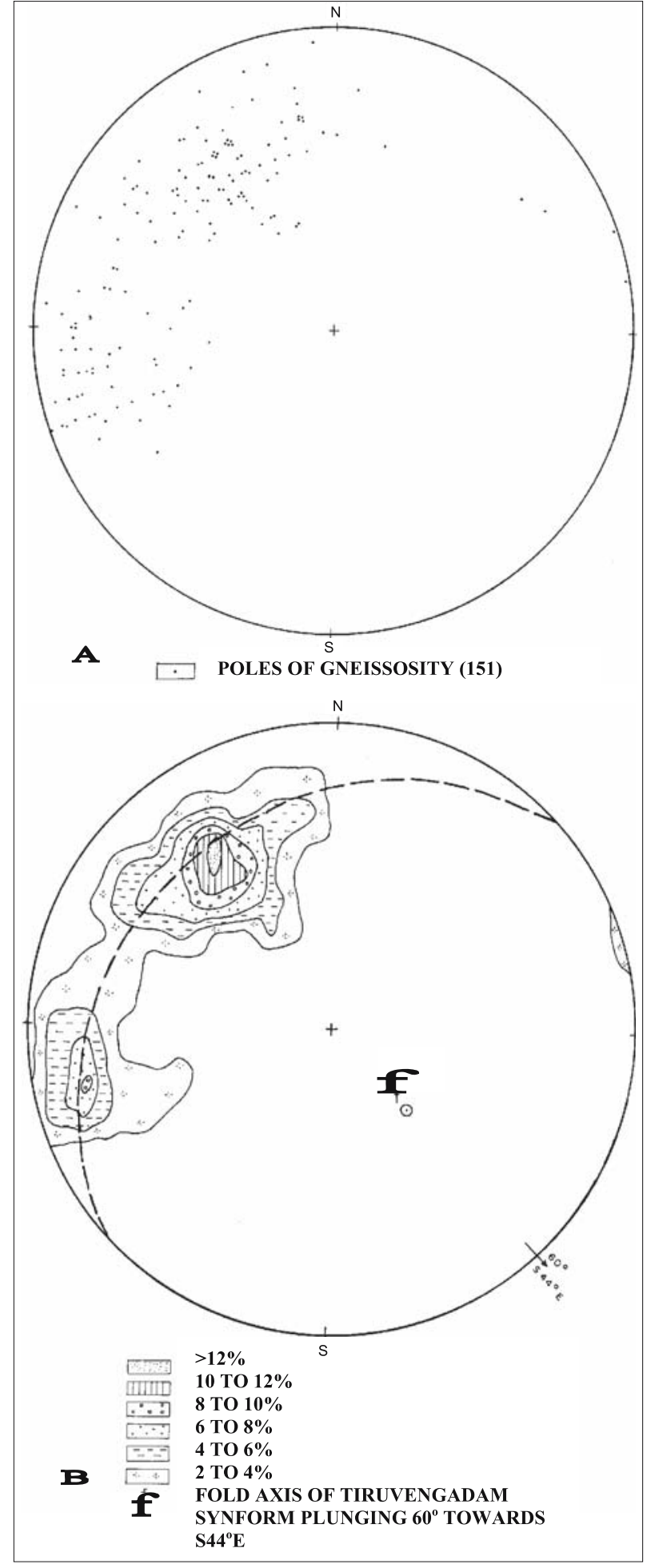

Figure 14. Lower hemisphere equal-area projection for Tiruvengadam synform, which is an F3 regional scale warp. (A) In the low-lying plain area to the east of Western Ghats Foothill Fault (SE part of figure 2), the attitude of gneissosity (differentiated layering) in charnockite and granite gneiss was measured in the field at number of locations and 151 poles of the gneissosity were plotted on an equal-area net. (B) Then these poles were contoured to bring out the exact plunge amount and direction of this regional scale warp. From this contoured equal-area projection, the Tiruvengadam synform (TS in figure 2) is found to be plunging at $60^{\circ}$ towards $\mathrm{S} 44^{\circ} \mathrm{E}$. 
even in satellite imagery (figure 3). This open warp could have formed during the on-play of NNE-SSW compressive forces and so it is kept in F3 phase regional scale folding.

The southern limb of Kattappana antiform (striking WNW-ESE and dipping due south) extends up to Achankovil shear zone. The Achankovil shear zone trends WNW-ESE to NW$\mathrm{SE}$ and is about $150 \mathrm{~km}$ long with an average width of $8 \mathrm{~km}$ (GSI 2006). As the strongly developed foliation within this shear zone dips towards SSW to SW with moderate to steep amount, this shear zone as a whole could also be dipping towards SSW to SW. The southern limb of Kattappana antiform bordering the Achankovil shear zone (north of Achankovil River in figure 2) is extensively fractured and these fractures also strike WNW-ESE with moderate to steep dip towards SSW. Recently Guru Rajesh and Chetty (2006) proposed initial dextral movement followed by sinistral strike slip movement along Achankovil shear zone. Thus the southern limb of Kattappana antiform (F3 warp) extends below the Achankovil shear zone in the SW corner of the study area (figure 2). The northern limb of Kattappana antiform extends up to Kodaikanal Foothill Fault that rims around the Kodaikanal uplifted block (figure 2).

Between Kambam and Ganguvarpatti, along Kambam valley, many open folds belonging to F3 phase with axial traces trending NW-SE to WNW-ESE were reported (Balasubramanian and Sundarrajan 1997; Sundaravanan and Mullaivendan 1997; Sundaravanan and Sundarrajan 1999; Sundaravanan 2003). So F3 phase folding, probably due to on-play of compressive forces in NNE-SSW direction, affected the whole terrain (i.e., both the eastern and western blocks of Suruli shear zone). If we remove the effect of F3 phase folding in eastern and western blocks, the eastern block (hanging wall) is complexly folded and so stratigraphically older than the western block (footwall). As the more deformed (older) terrain moved over the relatively less deformed (younger) terrain, the Suruli shear zone is a thrust or reverse fault, probably of Proterozoic age.

Earlier it was mentioned that the width of Suruli shear zone and intensity of deformation within the shear zone decreases from north (Ganguvarpatti) towards south (Kadaiyanallur). In the northern part of Suruli shear zone, there are plenty of field evidences for involvement of dextral strike slip component (figure 16) apart from strong dip slip component. South of Kadaiyanallur, the Suruli shear zone seems to branch (splay) out from Achankovil shear zone (figure 2) and the pivot of Suruli shear zone (where the displacement is minimum to zero) is located in this area. It is suggested that the eastern block could have moved

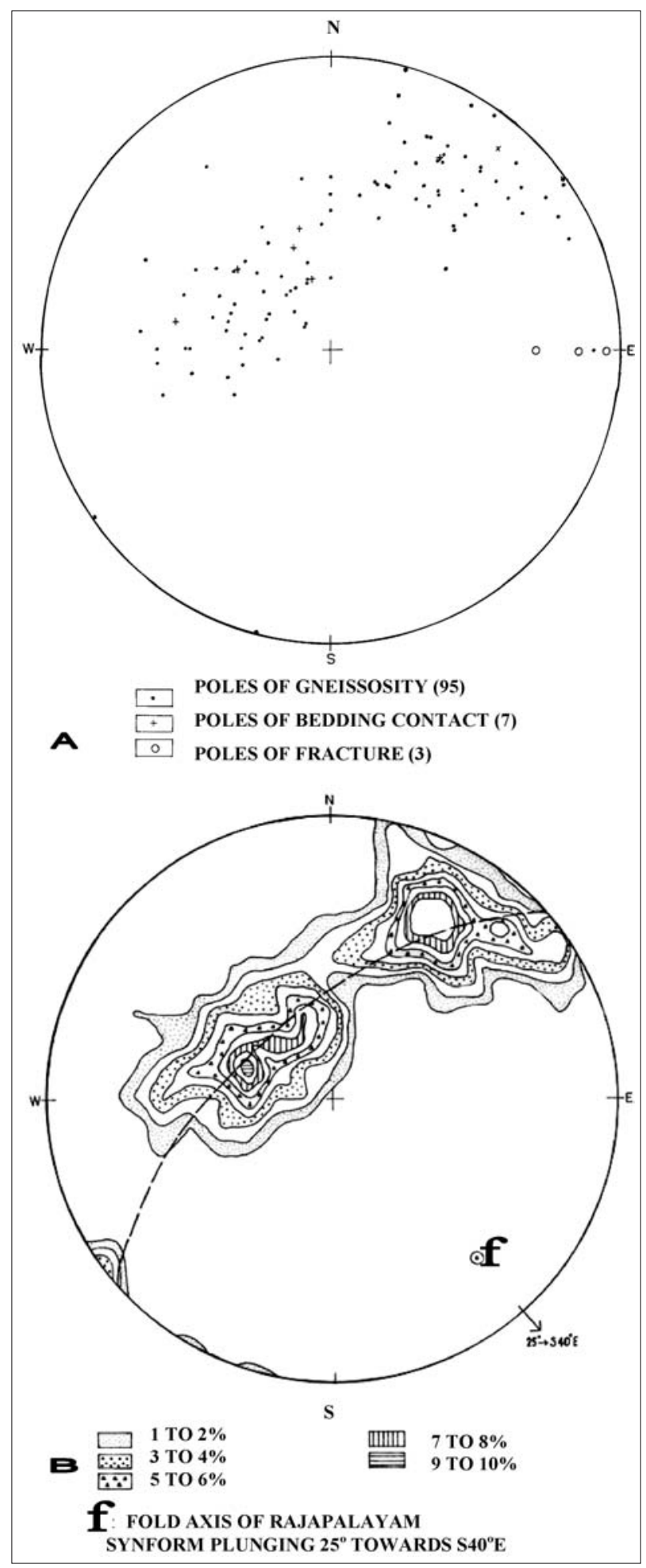

Figure 15. Lower hemisphere equal-area projection for Rajapalayam asymmetrical synform. Gneissic charnockite, khondalite, calc-granulite, granite gneiss and leucocratic granite intrusive are the main rock types involved in this folding. (A) The attitude of gneissosity and lithological contacts in both the limbs and the closure were measured in the field at a number of locations and their poles (95 poles of gneissosity, 7 poles of lithological contacts) were then plotted on an equal-area net. (B) These poles were then contoured to bring out the exact plunge amount and direction of this regional scale synform. The Rajapalayam synform is plunging at $25^{\circ}$ towards $\mathrm{S} 40^{\circ} \mathrm{E}$. 


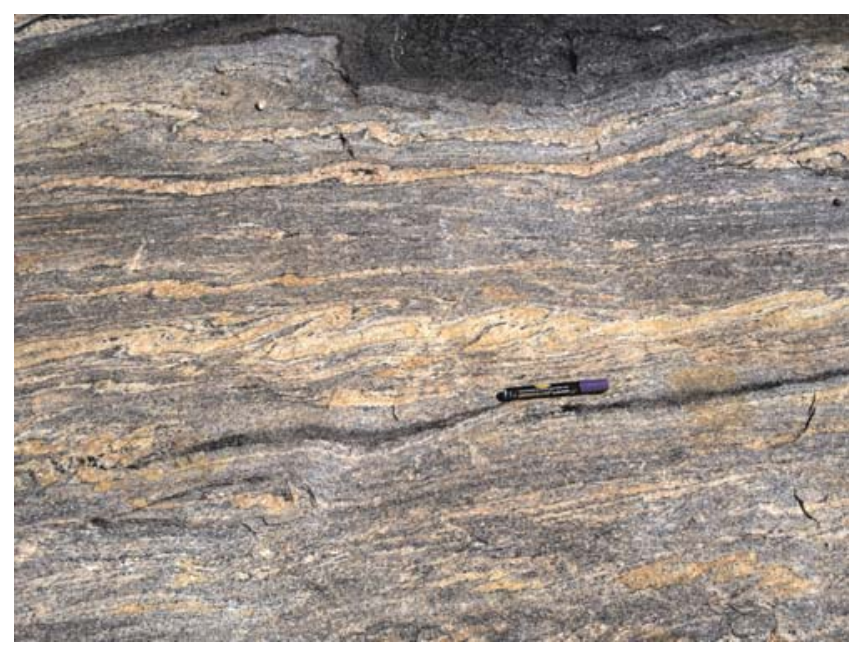

Figure 16. Within the Suruli shear zone there are many field evidences, such as ' $\mathrm{Z}$ ' shaped mesoscopic folding, offset pattern of broken bands (Loc: NE of Teni), that support involvement of minor dextral strike slip component.

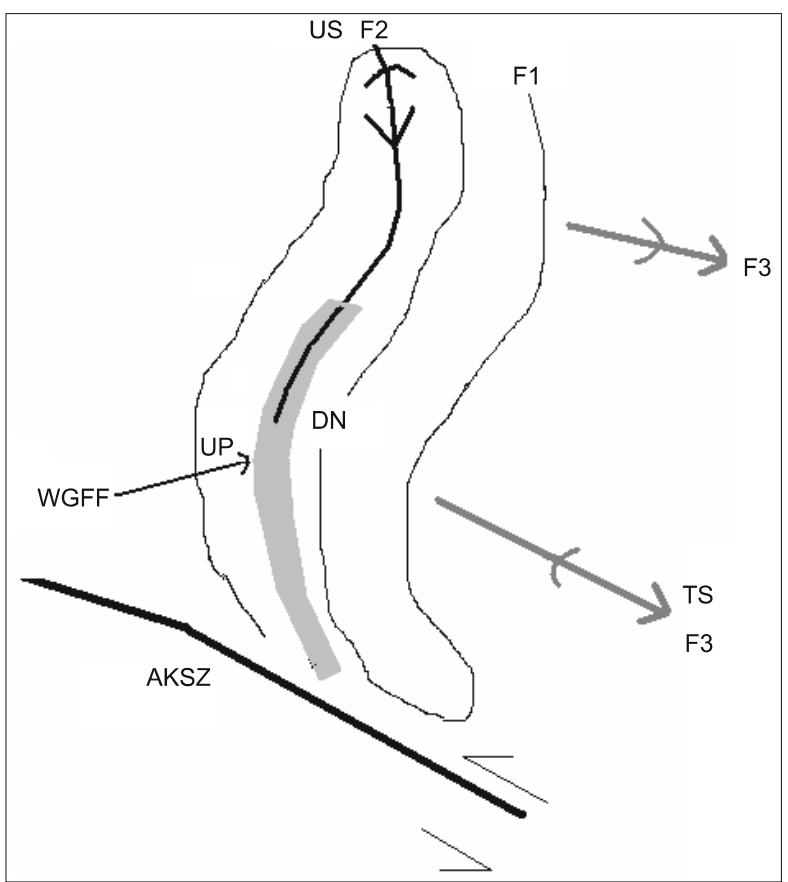

Figure 17. Sketch (not to scale) that shows the interference pattern of mega folds in Eastern Block of Suruli shear zone. This interference pattern seems to support the sinistral sense of strike slip movement along Achankovil shear zone (AKSZ) as proposed by Guru Rajesh and Chetty (2006). F1: F1 fold belt, US: Usilampatti synform (F2 mega fold), TS: Tiruvengadam synform (F3 mega fold), WGFF: Western Ghats Foothill Fault (UP: Up thrown block, DN: Down thrown block, mostly soil covered).

relatively upwards over the western block with a counterclockwise rotational movement (pivot in the south near Kadaiyanallur) and so the Suruli shear zone could be a rotational thrust or rotational reverse fault.

\section{Discussion and conclusion}

The Suruli ductile shear zone extends from just west of Kadaiyanallur in the south to Ganguvarpatti in the north over a length of $150 \mathrm{~km}$. The width and intensity of deformation within the shear zone increases from south to north. Between Kadaiyanallur and Kambam, the shear zone extends roughly in N-S direction. From Kambam, it swerves towards NE and then towards ENE near Ganguvarpatti. Between Kambam and Ganguvarpatti, there are many mylonite outcrops with the mylonite foliation dipping around $30^{\circ}$ towards SE to SSE. The transposed foliation all along this shear zone dips towards east only and so the eastern block is the hanging wall and the western block is the footwall of this shear zone.

The eastern block is more complexly deformed than the western block. In the eastern block, there are three distinct phases of regional scale folding (F1, F2, and F3) and the topography is controlled by the interference pattern of these three phases of regional scale folding (figure 17). On the contrary, the western block recorded only the last phase (F3) regional scale folding. It is suggested that the last phase (F3) regional scale folding (probably due to NNE-SSW compressive forces) affected the whole terrain (i.e., both the eastern and western blocks) after the eastern block (older terrain) moved over the western block (relatively younger terrain) along the Suruli shear zone. The Suruli shear zone is a thrust or reverse fault. As the width and intensity of deformation within the shear zone decreases from north to south, the amount of displacement along this shear zone could also be decreasing towards south. So it is a rotational thrust or rotational reverse fault with the pivot (minimum displacement) located in the south near Kadaiyanallur. As the pivot of Suruli shear zone is located very close to Achankovil shear zone that extends WNW-ESE (dip towards SSW), here it is suggested that the Suruli shear zone could be splaying (branching) out from Achankovil shear zone. In a nutshell, we can consider the Suruli shear zone as a splay, rotational thrust or reverse fault and this type of shearing is reported for the first time in this part of Southern Granulite Terrain.

During fieldwork, we observed charnockite and granite intrusives and crystalline limestone veins are structurally controlled and they need to be studied in detail. Just south of Peraiyur and in Krishnan Kovil (10 km NE of Srivilliputtur), there are denudational hills of massive, non-gneissic charnockite surrounded by gneissic charnockite and this massive, non-gneissic charnockite could be an intrusive type in the hinge zone of Usilampatti synform. Similarly at Maiparai, in the hinge 
zone of Tiruvengadam synform (TS in figure 2), massive, non-gneissic charnockite is exposed and it could be younger to the gneissic charnockite and granite gneiss that surround it. Another massive, non-gneissic charnockite is exposed at Kunnur, very close to Suruli shear zone, and here also it is observed within the gneissic charnockite. The massive, non-gneissic charnockite seems to have intruded in the hinge zones of regional scale folds and in weaker zones and so it could be structurally controlled.

Similarly there are different pulses of granite intrusion in this area. The earliest granite intrusive of smaller dimension was stretched and boudinaged and these boudins are aligned along the gneissosity in host charnockite like boudins of basic granulite. The later granite intrusives are larger in dimension and they intruded along the gneissic planes in the host charnockite. These are syntectonic intrusions as the gneissic layering in the granite intrusive is parallel to the gneissosity in the host charnockite. In Rajapalayam synform area, this granite intrusive (leucocratic type) is folded along with the host rocks like gneissic charnockite, granite gneiss, khondalite and calc-granulite and so this granite that is being quarried at Mottamalai in the eastern steep limb of this synform, should have been emplaced before F3 phase regional scale folding. The granite intrusives that are undeformed and non-gneissic are exposed near Tevaram (close to Suruli shear zone) and at Panpuli (close to Achankovil shear zone) and they are post-tectonic (post F3).

Apart from undeformed pegmatite and quartz veins, there are veins with perfectly developed calcite crystals and this crystalline limestone is being quarried at Alangulam and in between Rajapalayam and Sankarankovil (figure 2). It is traditionally believed that crystalline limestone is associated with calc-granulite and also belongs to the same stratigraphic status as that of calcgranulite (GSI 2006). But in the above-mentioned quarry sites, there is no exposure of calc-granulite and here these calcite crystal rich veins are mostly aligned along the gneissosity in host charnockite. However, there are also irregular veins in the host charnockite and these could be vein fillings in the cracks and crevices in the host charnockite. The calcite crystals in these veins are undeformed (without planar fabric development) and these veins are entirely different from calc-granulite in which the fine layering is highly contorted. The people working in the quarry sites know that the quality and quantity of crystalline limestone veins decrease with depth. In other words, they are more common close to the surface level than at depth. In this work it is suggested that there may be a limestone deposit in Tiruvengadam synform and the solution rich with calcium carbonate may have percolated downwards from this limestone deposit into the gneissosity, cracks and crevices of the underlying charnockite. The calcium carbonate that was precipitated as veins may have recrystallised at a later stage and the original limestone deposit also may have eroded away. As there is no evidence for deformation (such as planar fabric development) in these calcite crystal rich veins, the remobilisation and recrystallisation could have happened after F3 (post-tectonic). The Kankar in soil profile over the charnockite having crystalline limestone veins is another example of remobilisation of calcium carbonate in recent geological times.

\section{Acknowledgements}

The authors carried out Specialised Thematic Mapping (STM) of Rajapalayam-Sankarankovil area during Field Season 2006-2007 and 20072008 and during this period they also undertook field verification of aerial photo-geological details in the surrounding areas to understand the regional structural setup of this part of Madurai block of SGT. In this context, the authors express profuse thanks and gratitude to Shri. A Sundaramoorthy, Deputy Director General, Geological Survey of India, Central Head Quarters, Kolkata, Shri H James Maharaja Singh, Director (Retired) and Shri. N Singaram, Director, STM (Rajapalayam) for their support and encouragement. The authors also express gratitude to two anonymous reviewers of JESS and Dr Talat Ahmad of University of Delhi for advising many important suggestions for improving the content of this paper.

\section{References}

Balakrishnan P, Bhattacharya S and Anil Kumar 1985 Carbonatite body near Kambammettu, TN; J. Geol. Soc. India 26 418-421.

Balasubramanian E and Sundarrajan P 1997 Geology of Cumbam lineament zone around Periakulam within the structural conjunction zones in parts of Madurai Dist., TN; Geological Survey of India Field Season 1993-1994.

Chetty T R K 1995 Structural interpretation of high grade belts of south India using remotely sensed data; NMRMS Bulletin 19 34-37.

Chetty T R K 1996 Proterozoic shear zones in Southern Granulite Terrain; Memoir Gond. Res. Gr. 3 77-89.

Drury S A and Holt R W 1980 The tectonic framework of the south Indian craton - a reconnaissance involving LANDSAT imagery; Tectonophys. $65 \mathrm{~T}_{1}-\mathrm{T}_{15}$.

Drury S A, Harris N B W, Holt R W, Reeves Smith G J and Wightman R T 1984 Precambrian tectonics and crustal evolution in south India; J. Geol. 92 3-20.

Francis Anto K, Janardhan A S and Siva Subaramanian P 1997 A new sapphirine occurrence from Kambam valley, 
TN and its possible relation to Pan-African tectono thermal event; Curr. Sci. 73 792-796.

Gopalakrishnan K, Sugavanam E B and Venkata Rao V 1975 Are there rocks older than Dharwars? A reference to rocks in Tamil Nadu; Ind. Mineralogist 16 26-34.

Grady J C 1971 Deep main faults in South India; J. Geol. Soc. India 12 56-62.

GSI 2006 A manual of the Geology of India; Geol. Sur. India Spec. Publ. 77(1,1) 346-486.

Guru Rajesh K and Chetty T R K 2006 Structure and tectonics of Achankovil shear zone, southern India; Gondwana Res. 10 86-98.

Harris N B W and Santosh M 1993 Chronological constraints on granulite formation in southern India and Sri Lanka; Geol. Soc. India Memoir 25 361-379.

Harris N B W, Santosh M and Taylor P N 1994 Crustal evolution in South India: Constraints from Nd isotopes; J. Geol. 102 139-150.

Rajeshdurai P, Srinivasan V and Swain A K 2008 Metamorphic evolution of granulites around Rajapalayam area, Madurai Block, Southern Granulite Terrain, Tamil Nadu; Geol. Surv. India Spec. Publ. 91 45-60.

Sanjeevi S and Aparna S Bhaskar 2008 Satellite derived Digital terrain and perspective models. An aid to teach geological mapping; J. Geol. Soc. India 71 214-222.
Santosh M 1996 The Trivandrum and Nagercoil granulite blocks; In: The Archaean and Proterozoic terrains in southern India within East Gondwana; Gond. Res. Gr. Memoir 3 243-356.

Srinivasan V and Rajeshdurai P 2009 Study of the granulite and associated rocks of Rajapalayam-Sankarankovil area of Southern Granulite Belt; Geol. Surv. India Field Season 2006-07, 2007-08.

Sundaravanan D 2003 Study of the southern continuity of Suruli Ar lineament in Kambam valley, Teni Dist., TN; Geol. Surv. India, Field Season 1999-2000.

Sundaravanan D and Baskaran R 1998 Report on the study of Vaigai lineament zone around Vattalagundu within structural conjunction zones in parts of Madurai and Dindigul Anna districts, TN; Geol. Surv. India, Field Season 1994-1995.

Sundaravanan D and Mullaivendan T 1997 Study of Kambam lineament zone around Chinnamanur within structural conjunction zones in parts of Madurai Dist., TN; Geol. Surv. India, Field Season 1993-1994.

Sundaravanan D and Sundarrajan P 1999 Study of the structural conjunction zone around Ganguvarpatti and the lineament zone around Sakkanurani in parts of Dindigul and Madurai districts, TN; Geol. Surv. India, Field Season 1995-1996. 